a draped woman in the Louvre: this statue was aequired in 1829 by the former owner at Halicarnassus : though of good Greek work, it does not seem to have belonged to the Mausoleum. 3. Lechat: the archaic Elgin head in the British Musenm (Cat. 150) is the head of a Sphinx. 4. S. Reinach: suggests the restoration, on the authority of Cyriac, of a new sculptor's name, Thrasyxenos of Paros. 5. Pottier : continues his series of 'documents céramiques' of the Louvre: (ii) vases of Ionian type; Ionism in Attika. 6. Joubin : publishes two decrees of proxetia and a deed of enfranchisement found by hin at Stratos in 1892. 7. Lemnios : two inseriptions of Cyzicus. 8. Sroronos: a long article on the numismatics and history of Mykonos. 9. Diehl : publishes an inseription in Greek and Latin found in 1889 by Cousin at Ali-faradin on the borders of Pisidia and Kibyratis : it is a rescript of the emperors Justin and Justinian, assuring imperial protection to the oratory of St. John, A.D. 527. 10. Lechat and Radet: thirty-nine inscriptions of Mysia (cf. ante xii. p. 187). 11. Legrand : sixty inscriptions of Mysia and Bithynia. 12. Diamantaras: coins of Lycia. 13. Weil publishes the text of the Delphic hymn; and 14. S. Reinach gives the new fragments with musical notation and a long critical study of their bearing on our knowledge of Greek music.

Institute. Homolle's report on Delphi, and (p. 616) two Delphian inscriptions giving the accounts of the temple administration : Svoronos' interpretation of astronomical types on coins (p. 618), applied to coins of Crete (p. 621), especially the famous Gortyna type. News and correspondence: Athens, Peloponnesus, Islands, \&c. including three new Orphic inscriptions from Eleutherae (cf. ante, p. 121).

C. $\mathrm{s}$.

\title{
OBITUARY.
}

\section{WILLIAM ALEXANDER GREENHILL, M.D.}

As the only English physician of the present century who had devoted himself to the ancient literature of his profession, Dr. Greenhill claims some mention in the pages of the Classical Review. Very full and appreciative notices have appeared in the Athenaeum and the Guardian, as well as in the local papers, and in these his manysided activity, disinterested character, and sound and zealous churchmanship have been set forth in attractive colours. We shall here speak of him chiefly as the exponent of the Greek and Latin, and, incidentally, of the Arabic medical literature.

William Alexander Greenhill was born on Jan. 1, 1814, of a family which had an hereditary connexion with the Stationers' Company; his father having been treasurer of the Company, his elder brother, who died not long since, secretary and afterwards Master. In 1828 he went to Rugby at the beginning of Arnold's headmastership, and there he laid the foundation of his sound scholarship. $\mathrm{He}$ was a favourite pupil of the great Doctor, whose niece he ultimately married; and among such schoolfellows as Deans Stanley, Vaughan, and Lake, he was regarded as not the least promising of the brilliant band.

In 1832 he went to Trinity College, Oxford, where he held an exhibition. Here he at first gave himself up to desultory reading, instead of working for the schools : in after life he attributed this to the inferiority of the college lectures as compared with Arnold's teaching, but owned that be had acted priggishly in giving way to this feeling.

After a year or two he thought better of it, but it was then too late to read for honours, and in the end he took no degree in Arts, graduating M.B. in 1839 and M.D. in 1841 .

Together with his scientific studies he cultivated that literary side of the profession which he made so completely his own.

The Bodleian is rich in Arabic MSS., and it is understood that these, as well as printed sources, were laid under contribution. On his marriage he settled in Oxford, and began practice as a physician. Here he was one of Newman's parishioners, and for some time his churchwarden. His tirst publication, in 1842, was the Greek text of the anatomical treatise of Theo-

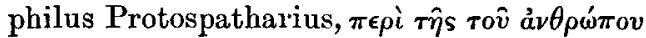
$\kappa a \tau \alpha \sigma \kappa \epsilon \hat{\eta} \mathrm{s}$, in a more complete form than had yet appeared. In the same year he contributed the medical articles to Dr. (afterwards Sir William) Smith's Dictionary of Antiquities. In the last edition of this work he was the only one of the original writers (except the late Dr. Leonhard Schmitz to a slight extent) who revised his own contributions. Some years later he wrote the lives of the ancient physicians for the Dictionary of Biography in the same series. In 1844 he was chosen by the Sydenham Society to edit the Latin works of its eponymous hero. Soon afterwards 
he translated the work of Rhazes On Smallpox and Measles for the first time from the original Arabic; previous English versions having been made from the Greek or Latin.

About 1852 Dr. Greenhill left Oxford and settled at Hastings. Here, in addition to his practice, he was the life and soul of every philanthropic and sanitary scheme, especially of the Hastings Cottage Improvement Society. He was also conspicuous in church and parish work; and the notices which have appeared since his death testify to the affection and reverence with which he was regarded by his fellow-townsmen. His old age was not free from sorrows. His elder daughter died of consumption, and his elder son was cut off in the midst of a promising career as an undergraduate; Mrs. Greenhill did not long survive this double loss. His literary work continued. Some years ago he brought out an elaborate edition of Sir Thomas Browne's Religio Medici, and at the time of his death was engaged upon the same authors Hyarnotaphia. He also contributed largely to Notes and Queries, and to the Dictionary of National Biography, the last volume of which, published since his death, includes the life of Dr. J. B. Mozley, the Regius Professor of Divinity. The subjects of his biographies were mostly Oxford celebrities. Besides his distinguished schoolfellows already mentioned, he was the friend of almost every eminent Oxonian of his time; of Pusey, Newman and Keble ; of Deans Church, Goulburn, Liddell and Scott; of Dr. Mozley; of Dr. Ogle and Sir Henry Acland, Regius Professors of Physic; and of Mr. Gladstone. $\mathrm{He}$ had long suffered from a heart trouble, and on Sept. 19 he passed away after two hours' illness, in his 81st year; having kept up his literary labours to the last. A son and a daughter survive him.

W. W.

\section{SUMMARIES OF PERIODICALS.}

\section{Classical Studies in honour of Fenry Drisler. \\ New York, Macmillan and Co. 1894.}

This sumptuous volume commemorates in German fashion the fiftieth year of Dr. Drisler's official connestion with Columbia College. It consists of twentyone papers by his pupils on various subjects connected with classical philology or archaeology, with the exception of three which are concerned with oriental literature. (1) On the meaning of nauta and viator in Hor. Sat. i. 5, 11-23, by S. G. Ashmore. After an examination of various parallel passages and the views of commentators the writer concludes that the viator is a "man on foot, whose destination lay in the same direction as that of Horace's party, and who was too poor to pay his fare by boat. $\mathrm{He}$ joins the nauta who is guiding the inule, and the two men sing as they go.' (2) Anaximander on the prolongation of infancy in man, by $\mathbf{N}$. M. Butler. This note on the history of the theory of evolution calls attention to the remarkable way in which certain pre-Socratic thinkers, espécially Anaximander and Xenophanes, anticipated some modern discoveries. It is clear, for instance, from a fragment of Anax. that he 'observed and understood the main point in connection with the prolongation of the period of infancy in man ; namely, that it affords a needed opportunity for the adjustment of the complex physical and psychical activities to their environment, - a point which has recently been drawn ont by Messrs. Spencer, Fiske, and Wallace. (3) of two passages in Euripides Medea, by M. L. Earle. In the much-vexed I. 12 Dr. Earle would read $\partial \rho \gamma \hat{\eta}$ for $\phi v \gamma \hat{p}$ after Musgrave,

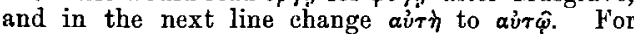

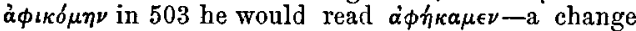
which hardly seems required. (4) The preliminary military service of the equestrian Cursus Honorum, by J. C. Egbert, junr. From a study of the inscrip- tions of the empire it appears that the equestrian military service during the three centuries of its history assumed four different forms. I. Tribunatus militum, II. Tribunatus cohortis vigilum, cohortis urbanae, cohortis practoriae, IIJ. Praefectus cohortis, tribunus militum, praefectus alae, IV. Praefectara alae. The praefectura (castrorum) legionis became a part of the militiae equestres under Septimius Severus. At first this military service merely led to civil offices, but from the time of Hadrian the military career assumes an importance of its own. References to Zoroaster in Syriac and Arabic literalure, by R. J. H. Gottheil. (6) Literary frauds among the Greeks, by A. Gudeman. This paper draws attention to some of the more important and interesting literary frauds beginning with Onomacritus (Hdt. vii. 6). The entire classical period gives no clear case, which will not surprise us in such an age of originality of thought and expression, and at a time when no class of reading public had yet arisen. They first appeared in the guise of interpolations, a common example of which is the practice of actors to tamper with the text of the dramatists. The centuries following the time of Aristotle were fruitful in forgeries. (i) In poetry Heraclides Ponticus is instanced as introducing us to the mythical predecessors of Homer, viz. Philammon, Linos, and Amphion. Some of the odes of Sappho, the didactic sayings of Theognis, and the erotic songs of Anacreon were so much diluted with the effusions of unknown bards that it is often most difficult and sometimes impossible to separate the genuine from the spurious. (ii) In philosophical literature we find a long list of forgeries, which owe their existence principally to two causes, one being a pecuniary inducement and the other a desire to increase for purposes of pro. paganda the material of certain sects, particularly 